\title{
Medicinal Plants in Basic Care: A Study of Clinical Practice
}

\author{
Carlos A.S. Souza ${ }^{1, *}$, Wesley M.G. Andrade', Thaís S. Ramos' ${ }^{1}$, Alex J. S. Filho ${ }^{2}$, Anderson L. Freitas', Tamires C. \\ Lima', Ângelo R. Antoniolli' ${ }^{3}$, Wellington B. Silva', Francilene A. Silva'
}

\section{Carlos A.S. Souza ${ }^{1, *}$, Wesley \\ M.G. Andrade', Thaís S. \\ Ramos ${ }^{1}$, Alex J. S. Filho', \\ Anderson L. Freitas ${ }^{1}$, Tamires \\ C. Lima' ${ }^{1}$ Ângelo R. Antoniolli ${ }^{3}$ \\ Wellington B. Silva ${ }^{1}$, \\ Francilene A. Silva ${ }^{1}$}

'Departamento de Farmácia, Universidade Federal de Sergipe, Av. Marechal Rondon, $s / n$, Cidade Universitária, São Cristóvão, Sergipe 49100-000, BRAZIL.

2 Departamento de Biologia, Universidade

Federal de Sergipe, Av. Marechal Rondon,

$s / n$, Cidade Universitária, São Cristóvão,

Sergipe 49100-000, BRAZIL.

${ }^{3}$ Departamento de Fisiologia, Universidade

Federal de Sergipe, Av. Marechal Rondon,

$s / n$, Cidade Universitária, São Cristóvão,

Sergipe 49100-000, BRAZIL.

\section{Correspondence}

Carlos A.S. Souza

Department of Pharmacy, Federal

University of Sergipe, Av. Marechal

Rondon, s/n, Cidade Universitária, 49100

000, São Cristóvão, Sergipe, BRAZIL.

Tel:/Fax: +55-79-991511329

E-mail: carlos.953@gmail.com

History

- Submission Date: 22-04-2019

- Review completed: 08-05-2019.

- Accepted Date: 09-05-2019.

DOI : 10.5530/pj.2019.11.127

Article Available online

http://www.phcogj.com/v11/i4

Copyright

(C) 2019 Phcogj.Com. This is an openaccess article distributed under the term of the Creative Commons Attribution 4.0 International license.

\section{ABSTRACT}

According to World Health Organization, $80 \%$ of world population uses traditional practices for primary health care, and $85 \%$ of this shares the use of medicinal plants or plants-based preparations. Thus, the present work had as objective to investigate the profile of herbal medicine use as well as the conditions to the alive pharmacy implementation in four basic health units in the city of Aracaju, Sergipe, Brazil. For such, 84 family health professionals were interviewed about the use of medicinal plants. Concerning the indication of medicinal plants, $41.67 \%$ of the health staff prescribes medicinal plants, $55.95 \%$ reported never having prescribed medicinal plants and $2.4 \%$ abstained from responding. Despite the intention to use phytotherapy as a therapeutic practice, this practice is not yet fully inserted in the analyzed units due to factors such as lack of training and specific protocols to assist professionals in the use of medicinal plants and phytotherapics.

Key words: Traditional and Complementary Medicine, Phytotherapy, Healthcare Unit, Brazilian Unified Health System.

\section{INTRODUCTION}

According to World Health Organization (WHO), over the past years there was an increase of the countries that promote the traditional and complementary medicine through national policies and regulations with the aim of promoting the safe and effective use of integrative practices.

Medicinal plants constitute a rich source of biologically active compounds, showing their therapeutic potential to treatment and prophylaxis of various diseases. ${ }^{2}$ In this context, Brazil has gained visibility in the world scenario, since the great diversity of plants and raw material found in its territory can be useful for the manufacture of phytotherapics and other medicines. Besides serving as source for production of new drugs, plants are also popularly used as home remedies. ${ }^{3}$

Brazil, through the Unified Health System (SUS), has been stimulating the implantation of the phytotherapy through policies and programs that aim "to guarantee to the Brazilian population the safe access and rational use of medicinal plants and phytotherapics". ${ }^{3-5}$ According to Figueredo et al., ${ }^{6}$ the implementation of phytotherapy represents the incorporation of another therapeutic practice for the health professionals. In addition, it also provides the rescue of a millenarian practice together with scientific and popular knowledge.

Thus, the present study aimed to investigate the profile of medicinal plants and phytotherapics utilization in four basic units of the Family Health Strategy (FHS) located in Aracaju city - SE (Brazil), as well as the prescription/indication by the health staff.

\section{METHODOLOGY}

\section{Study design}

The present study is cross-sectional, descriptive, case ethnopharmacological, with quantitative and qualitative methods of collecting and analyzing data. The study was conducted in the period from August 2016 to July 2017 in four FHS basic health units of Aracaju city and was composed by community health agents (CHA), nurses, physicians and dental surgeons.

\section{Ethical approval for the study}

Ethical approval for this ethnopharmacological survey was obtained from the Ethics and Research Committee of the University Hospital of Sergipe (CAE: 61094816.6.0000.5546). The participants were adequately informed about the nature of study, and benefits and risks involved. The subjects who agreed to participate of the study signed a written consent document.

\section{Characterization of Brazilian health care}

Ever since 1988, the Brazilian Constitution has promised free public healthcare in all complexity levels through the SUS, founded by taxes and social contributions. The SUS, by means of FHS, has decentralized care coverage and proved to reduce common diseases, mortality rate, and unnecessary admissions.?

\section{Alive pharmacy}

The alive pharmacy presents in the health units constitute medicinal gardens where are carried out activities such as cultivation, processing and management of medicinal plants, ensuring their correct and safe use in basic care.

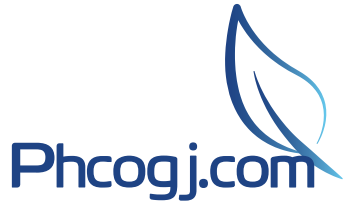

Cite this article: Souza CAS, Andrade WMG, Ramos TS, Filho AJS, Freitas AL, Lima TC, et al. Medicinal Plants in Basic Care: A Study of Clinical Practice. Pharmacog J. 2019;11(4):796-802 


\section{Health units' selection}

The health units were selected based on the following criteria: presence of medicinal garden in the health unit or use/prescription of medicinal plants by FHS staff. The selected units are in the east, west, south and north regions of Aracaju city.

\section{Family health strategy}

Family Health Strategy (FHS) has evolved into a robust approach to provide primary care for defined populations by deploying interdisciplinary health care teams. Family health team includes a physician, a nurse, a nurse assistant, and four to six full-time community health agents. These professionals, organized geographically, cover populations of up to 1.000 households each, with no overlap or gap between catchment areas. ${ }^{8}$

\section{Collection of medicinal plants from health facilities}

The medicinal plants were collected in the health units that had medicinal gardens and, later, the selected species were identified by the botanist PhD. Ana Paula do Nascimento Prata, Biology Department, Federal University of Sergipe. A representative exsiccate of each collected species was deposited at the herbarium of the Biology Department of the Federal University of Sergipe.

\section{Structural analysis of the medicinal garden/alive pharmacy}

The physical structure of the health units was analyzed to verify the presence of cultivated area (with availability of at least five hours of sun), slope of the land and proximity of sources of pollution (such as crops that use agrochemicals and proximity to roads).

\section{Questionnaire}

A script and semi-structured questionnaire were elaborated and tested in a pilot study. After the required adjustments, the interviews were carried out with the participants of the research. The sample used in the pilot study wasn't part of the final sample.

The research instrument consisted of 33 items divided into six domains, which characterize: social profile, knowledge about alive pharmacy and its legislation, physical structure of the health unit regarding the possible implantation of medicinal garden, knowledge about phytotherapy and use of medicinal plants, believe about the use of medicinal plants, and professional performance in the field of phytotherapy.

To evaluate the knowledge about alive pharmacy and its applicability in the Primary Health Care (PHC) was developed a scale that characterizes the knowledge as inadequate (0-3 points), partial (4-5 points) and adequate (6-8 points). The evaluated categories were management, form of cultivation and collection, processing, storage, handling, dispensing and commercialization knowledge.

\section{Data analysis}

The data were analyzed using the statistical softwares BioEstat 5.0 and Epi info for Windows, IOP, which allowed a descriptive analysis of the mentioned variables. ${ }^{9}$ Concerning the open questions, these were analyzed based on the Bardin content analysis. This method seeks to understand the meaning of the information given by the participants in the questionnaires, interpreting their explicit and implicit meanings. ${ }^{10}$

Among the techniques suggested, a grouping of terms or key expressions with similar meanings was chosen. To perform the interpretation of the results obtained in this process, it was based on theoretical references of the phytotherapy field as an important area of knowledge and practice of cultural rescue in PHC.

\section{RESULTS}

\section{Profile of health staff}

Among the interviewees, $84.52 \%(\mathrm{n}=71)$ were female and only $8.39 \%$ $(n=13)$ were male. The average age of participants was 42.83 years $( \pm$ 8.43). Regarding the profession, $69.05 \%(\mathrm{n}=58)$ were CHA, $15.48 \%$ $(\mathrm{n}=13)$ were nurses, $10.71 \%(\mathrm{n}=9)$ were physicians and $4.76 \%(\mathrm{n}$ $=4$ ) were dental surgeons. Regarding the graduation time of health professionals (physicians, nurses and dental surgeons), they had a mean of 14.8 years $( \pm 7.7)$.

\section{Knowledge about medicinal plants and phytotherapy legislation}

Referring to legislation on medicinal plants and phytotherapy, 67\% (n = 39) of the CHA claimed to know the National Policy of Medicinal Plants and Phytotherapics (NPMPP $),{ }^{4}$ however, $60 \%(\mathrm{n}=35)$ of the interviewees didn't know the National Program of Medicinal Plants and Phytotherapics (NPMPP) from Health Ministry. ${ }^{5}$ Regarding graduated health professionals (GHP), 80\% reported not knowing the NPMPP (Table 1). Further, it was also investigated the knowledge of health professionals about the list of medicinal plants of interest to SUS, ${ }^{11}$ $92.77 \%$ of the professionals reported not knowing the RENISUS and $62.5 \%$ of the medicinal plants found in alive pharmacy are not part of RENISUS. This list includes medicinal plants with potential to generate products of interest to SUS. The selection criteria were used by folk medicine and plants whose effects have scientific evidence. In addition, priority was given to the inclusion of native plants of different biomes in the country and those that could benefit the most common diseases in Brazil. common diseases in Brazil.

\section{Physical structure}

From the four evaluated health units, only one possessed a medicinal garden, characterizing the model of Alive Pharmacy I. ${ }^{12}$ In this alive pharmacy model is developed the cultivation activities from the installation of medicinal gardens in alive pharmacies of the community and/or SUS units. Thus, the population has availability of fresh medicinal plants as well as guidance on the correct preparation and use of homemade preparations. However, this medicinal garden was built on sloping ground and the literature recommends planting on flat ground. ${ }^{13,14}$

Regarding the other three health units, they possessed adequate cultivation area and availability of sun exposure for at least five hours, as recommended by the literature. ${ }^{13,14}$ Further, it was observed that all the health units were protected against strong wind and had good availability of fresh water for irrigation. However, two evaluated health units were located nearby pollution sources (sewage and septic tank), impairing the implantation of the medicinal garden.

\section{Medicinal plants}

The medicinal plants collected in health unit that possessed medicinal garden were of the following families: Lamiaceae (18.18\%), Euphorbiaceae, Myrtaceae (13.64\% each), Amaranthaceae, Anacardiaceae, Asteraceae, Caricaceae, Costaceae, Crassulaceae, Meliaceae, Poaceae, Rubiaceae, Sapindaceae, Urticaceae and Verbenaceae (4.55\% each) (Table 2). Among medicinal plants cultivated in the medicinal garden from health unit, $69.57 \%$ was not included in RENISUS.

\section{Knowledge about phytotherapy and use of medicinal plants}

Regarding the perception about the meaning of medicinal plants, herbal medicines and home remedies by the health staff, it was observed a 
Table 1: Knowledge about medicinal plants legislation. Aracaju, from August 2015 to July 2016.

\begin{tabular}{|c|c|c|}
\hline Variable & Frequency & $\%$ \\
\hline \multicolumn{3}{|c|}{ CHA $^{1}$ knowledge about NPMPP ${ }^{2}$} \\
\hline Yes & 39 & 67.24 \\
\hline No & 19 & 32.76 \\
\hline \multicolumn{3}{|c|}{ CHA knowledge about NPGMPP ${ }^{3}$} \\
\hline Yes & 23 & 39.66 \\
\hline No & 35 & 60.34 \\
\hline \multicolumn{3}{|c|}{ GHP ${ }^{4}$ knowledge about NPMPP } \\
\hline \multicolumn{3}{|l|}{ Physician } \\
\hline Yes & 6 & 66.67 \\
\hline No & 3 & 33.33 \\
\hline \multicolumn{3}{|l|}{ Nurse } \\
\hline Yes & 4 & 30.77 \\
\hline No & 9 & 69.23 \\
\hline \multicolumn{3}{|c|}{ Dental surgeon } \\
\hline Yes & 1 & 25 \\
\hline No & 3 & 75 \\
\hline \multicolumn{3}{|c|}{ GHP knowledge about NPGMPP } \\
\hline \multicolumn{3}{|l|}{ Physician } \\
\hline Yes & 3 & 33.33 \\
\hline No & 6 & 66,66 \\
\hline \multicolumn{3}{|l|}{ Nurse } \\
\hline Yes & 1 & 7.70 \\
\hline No & 12 & 92.30 \\
\hline \multicolumn{3}{|c|}{ Dental surgeon } \\
\hline Yes & 1 & 25 \\
\hline No & 3 & 75 \\
\hline
\end{tabular}

${ }^{1}$ Community Health Agents; ${ }^{2}$ National Policy of Medicinal Plants and Phytotherapics; ${ }^{3}$ National Program of Medicinal Plants and Phytotherapics; ${ }^{4}$ Graduated Health professionals.

Table 2: Plants identified in the basic health unit. Aracaju, August 2015 to July 2016.

\begin{tabular}{|c|c|c|c|}
\hline Scientific name & Popular name & Used part & Voucher \\
\hline Croton heliotropiifolius Kunth & Velame & Leaves & 35067 \\
\hline Kalanchoe crenata (Andrews) Haw. & Saião & Leaves & 35068 \\
\hline Plectranthus barbatus Andrews & Boldo & Leaves & 35069 \\
\hline Jatropha gossypiifolia L. & Pinhão-roxo & Leaves & 35070 \\
\hline Melissa officinalis L. & Erva-cidreira & Leaves & 35071 \\
\hline Morinda citrifolia $\mathrm{L}$. & Noni & Fruit & 35072 \\
\hline Schinus terebinthifolius Raddi & Aroeira & Leaves & 35073 \\
\hline Mesosphaerum pectinatum (L.) Kuntze & Sambacaitá & Leaves & 35074 \\
\hline Stachytarpheta cayennensis Vahl. & Gervão & Leaves & 35075 \\
\hline Eugenia uniflora L. & Pitanga & Leaves and fruit & 35076 \\
\hline Azadirachta indica A. Juss. & Nim indiano & Leaves & 35077 \\
\hline Cymbopogon citratus (DC) Stapf & Capim-santo & Leaves & 35078 \\
\hline Costus spicatus (Jacq.) Sw. & Folha-da-costa & Leaves & 35079 \\
\hline Synedrella nodiflora (L.) Gaertn. & Folha-de-feiticeira & Leaves & 35080 \\
\hline Cecropia pachystachya Trécul & Embaúba & Leaves & 35081 \\
\hline Alternanthera brasiliana $\mathrm{L}$. & Penicilina, anador & Leaves & 35082 \\
\hline Syzygium cumini (L.) Skeels & Jamelão & Fruits, leaves, seeds and bark & 35083 \\
\hline Psidium guajava L. & Goiaba & Leaves and fruit & 35084 \\
\hline Carica papaya L. & Papaya & Leaves and fruit & 35085 \\
\hline Mentha spicata L. & Hortelã & Leaves & 35086 \\
\hline Aloe vera (L.) Burm. F. & Babosa & Leaves & 35.088 \\
\hline Apocynaceae Catharanthus roseus $\mathrm{L}$. & Vinca & Leaves & 35.087 \\
\hline Jatropha curcas L. & Mertiolate & Leaves & 35089 \\
\hline Trichilia emarginata (Turcz.) DC. & Tansagem & Leaves & 35091 \\
\hline
\end{tabular}


diversity of words/expressions $(\mathrm{n}=148)$, which were grouped in three thematic categories (Table 3 ).

\section{Knowledge about the legislation and management of the alive pharmacy}

When evaluating the variables related to knowledge about alive pharmacy (management, cultivation, collection, processing, storage, handling and dispensing), it was found that most interviewees (85\%, $\mathrm{n}=68$ ) had inadequate knowledge, $9 \%$ partial and only $6 \%$ adequate.

\section{Belief and use of medicinal plants}

It also investigated the use of medicinal plants and phytotherapics by the health professionals. Among the interviewees, $90 \%$ use medicinal plants, $6 \%$ do not use them, and $4 \%$ rarely use them.

Further, $97.62 \%$ believe in the therapeutic effectiveness of medicinal plants as home remedy. The terms/expressions associated with the justification of the belief in effectiveness were: "own knowledge", "effectiveness proven by a third part", "family member's indication", "disease cure", "do not need allopathic medicines", "being natural", "ease acquisition" and "scientific and popular proof".

The interviewees were also questioned about the therapeutic effectiveness of manipulated and industrialized herbal medicines, and $91.67 \%$ answered positively regarding effectiveness using the same terms/expressions when justifying the belief in the use of medicinal plants. It should be noted that the main terms to justify the non-use of phytotherapic and manipulated were: "not to rely on the quality of the manipulated/industrialized" and "properties loss after manipulation".

Professional work in the field of medicinal plants and phytotherapy

Regarding the knowledge of the health professionals about the use of medicinal plants by their patients, $97.62 \%(n=82)$ reported to known about the use of these by the patients, but $71.43 \%(n=60)$ of users did not request information (indication/prescription) on the medicinal plants used.

Regarding GHP, $68 \%$ stated to question the patient about the use of medicinal plants at the moment of the consultation. In addition, $68 \%$ of professionals stated that they were aware of the indication/prescription by other categories of health professionals.

When questioned about which professional categories (other than their own) prescribed/indicated medicinal plants and phytotherapics in the health unit, $31 \%$ reported the medical and nursing professionals, $23 \%$ $\mathrm{CHA}$, and $15 \%$ nursing auxiliaries. Regarding the act of prescribing/ indicating medicinal plants, $42 \%$ perform this practice in their work routine, $56 \%$ reported have never prescribed/indicated and $2 \%$ refrained from responding.

The medicinal plants most cited in the act of prescription were the following: Plectranthus barbatus Andrews (17.71\%, $\mathrm{n}=17)$, Melissa officinalis L. $(13.54 \%, \mathrm{n}=13)$, Foeniculum vulgare Mill. $(11.46 \%, \mathrm{n}=11)$,
Mesosphaerum pectinatum (L.) Kuntze $(9.38 \%, \mathrm{n}=9)$, Mentha spicata L. $(9.38 \%, \mathrm{n}=9)$, Schinus terebinthifolius Raddi $(6.25 \%, \mathrm{n}=6)$, Malva sylvestris $\mathrm{L} .(6.25 \%, \mathrm{n}=6)$, Chenopodium ambrosioides $\mathrm{L} .(6,25 \%, \mathrm{n}=6)$, Matricaria chamomilla L. $(5.21 \%, \mathrm{n}=5)$, Stryphnodendron barbatiman Mart. (5.21\%, $\mathrm{n}=5)$, Cymbopogon citratus (DC) Stapf $(4.17 \%, \mathrm{n}=4)$, Allium sativum L.(4.17\%, $\mathrm{n}=4)$, Aloe vera (L.) Burm. F $(4.17 \%, \mathrm{n}=$ 4) and Ocimum basilicum L. $(3.13 \%, \mathrm{n}=3)$. The Table 4 shows the therapeutic indication of the main plants cited in the act of prescription as well as their popular name.

\section{Knowledge/training on medicinal plants}

All health professionals interviewed reported that they did not attend any courses or were offered courses on medicinal plants and herbal medicines. The majority (76\%) described the need to include elective subjects about these themes in the graduation, meanwhile $24 \%$ believe that this inclusion should be done as compulsory subject.

\section{DISCUSSION}

The actions with medicinal plants and phytotherapy, long inserted in SUS, happen mainly FHS by the fundamentals and principles of this level of attention/strategy and the characteristic of the practice of phytotherapy, which involves interaction between knowledge, partnership in care, promotion and prevention actions..$^{15}$ Marques, et al. ${ }^{16}$ observed a great acceptance of the medical team regarding the use of alternative and complementary therapies in a health unit of the city of São João da Mata, Minas Gerais, Brazil

Most health professionals were female. This result is in accordance with other researches carried out in the primary health care that described the profile of the health staff in this level of care. For example, in 2011, Marsiglia, et al. ${ }^{17}$ carried out a study in 87 health units of the São Paulo city, São Paulo, Brazil. In this work, it was observed a prevalence of female in the units and half of the interviewees were aged between 21 and 40 years.

Regarding the interviewees' perceptions about medicinal plants, expressions referring to the cure of diseases were mentioned. In fact, medicinal plants represent an important therapeutic alternative in the scope of primary health care for the treatment of diseases. The medicinal herbs used in the prevention and treatment of diseases are a popular activity in the Brazil, being part of the everyday life of a large part of the Brazilian population, mainly in the interior cities located away from the large medical-hospital centers. ${ }^{18}$

Another perception found in the study refers to phytotherapics and their association with terms related to allopathic medicines such as correct dosage, industrialization and scientific evidence. Despite this correlation with allopathic drugs, there was an association between phytotherapics and absence of adverse effects, due to the concept of "natural" medicine. This perception can lead to damages to the health of users, given the idea of innocuousness of herbal medicines. Medicinal plants contain pharmacologically active ingredients, some of which might interact with synthetic drugs which, in turn, could endanger the health of patients. ${ }^{19}$

Table 3: Description of words/expressions associated with medicinal plants per the thematic category. Aracaju, August 2015 to July 2016.

\begin{tabular}{lcl}
\hline Thematic category & Frequency & Used expression \\
\hline Medicinal plants in PHC & 48 & $\begin{array}{l}\text { Heal (10), homemade natural remedy (9), effectiveness (7), therapeutic plant (7), treatment (6), tea plant (5), } \\
\text { prevention (4) }\end{array}$ \\
$\begin{array}{l}\text { Knowledge about herbal } \\
\text { medicines }\end{array}$ & 47 & $\begin{array}{l}\text { Medicine made of medicinal plants (14), industrialized herbal medicine (10), herbal medicine made in laboratory } \\
(4), \text { natural remedy (2), scientifically proven plant (2), without chemical components (12), right dosage (1) }\end{array}$ \\
$\begin{array}{l}\text { Home remedies for health } \\
\text { care }\end{array}$ & $53 \quad \begin{array}{l}\text { Homemade herbal medicine (31), teas (7), past generations (5), syrup (2), no security (2), made out of leaves } \\
\text { (1), plant remedy (1), therapeutic action (1), Non-industrialized (1), home phytotherapics (1), no guidance (1), } \\
\text { medicinal garden (1) }\end{array}$ \\
\hline
\end{tabular}

*Primary Health Care 
Table 4: Major medicinal plants prescribed by health professionals. Aracaju, August 2015 to July 2016.

\begin{tabular}{|c|c|c|c|c|}
\hline Scientific name & Popular name & Homemade & Therapeutic indication & Health care professional \\
\hline Plectranthus barbatus Andrews & "boldo" & Tea & $\begin{array}{l}\text { Cholagogue, choleretic, digestive } \\
\text { disturbances, hepatic stimulant, stomachic }\end{array}$ & $\begin{array}{l}\text { Nurse, physician, community } \\
\text { health agents }\end{array}$ \\
\hline Melissa officinalis L. & "erva cidreira" & Tea & $\begin{array}{l}\text { Stomach pain, diarrhea, flatulence, } \\
\text { headache, antihypertensive }\end{array}$ & $\begin{array}{l}\text { Nurse, physician, community } \\
\text { health agents, dental surgeon }\end{array}$ \\
\hline Foeniculum vulgare Mill. & "erva doce" & Tea & Stomach pain, anxiolytic, abdominal pain & $\begin{array}{l}\text { Nurse, physician, community } \\
\text { health agents }\end{array}$ \\
\hline $\begin{array}{l}\text { Mesosphaerum pectinatum (L.) } \\
\text { Kuntze }\end{array}$ & "sambacaitá" & Tea and poultice & Antimicrobial, anti-inflammatory & Nurse, community health agents \\
\hline Mentha spicata $\mathrm{L}$ & "hortelâ" & Tea & Flu, immune system stimulant, flatulence & Nurse, community health agents \\
\hline Schinus terebinthifolius Raddi & "aroeira" & Tea and poultice & Anti-inflammatory & Nurse, community health agents \\
\hline Chenopodium ambrosioides L. & "mastruz" & $\begin{array}{l}\text { Tea, juice, aqueous } \\
\text { extract }\end{array}$ & & $\begin{array}{l}\text { Nurse, physician, community } \\
\text { health agents }\end{array}$ \\
\hline Malva sylvestris $\mathrm{L}$. & "malva-branca" & Tea, homemade syrup & Stomach pain, diarrhea, toothache & $\begin{array}{l}\text { Nurse, health community health } \\
\text { agents }\end{array}$ \\
\hline Matricaria chamomilla L. & "camomila" & Tea & Flatulence, calming, & $\begin{array}{l}\text { Nurse, physician, community } \\
\text { health agents }\end{array}$ \\
\hline $\begin{array}{l}\text { Stryphnodendron barbatimam } \\
\text { Mart }\end{array}$ & "barbatimão" & Aqueous extract & $\begin{array}{l}\text { Antimicrobial, wound healing, Vaginal } \\
\text { itching and discharge }\end{array}$ & Nurse, community health agents \\
\hline $\begin{array}{l}\text { Cymbopogon citratus (DC) } \\
\text { Stapf }\end{array}$ & "capim santo" & Tea & High blood pressure, calming & $\begin{array}{l}\text { Nurse, physician, community } \\
\text { health agents }\end{array}$ \\
\hline Allium sativum $\mathrm{L}$. & "alho" & $\begin{array}{l}\text { Herbal tincture, } \\
\text { homemade syrup }\end{array}$ & High blood pressure, flu & $\begin{array}{l}\text { Nurse, physician, community } \\
\text { health agents }\end{array}$ \\
\hline Aloe vera (L.) Burm. F. & "babosa" & Leaf gel & Burns, wound healing & Nurse, community health agents \\
\hline Ocimum basilicum $\mathrm{L}$. & "manjericão" & $\begin{array}{l}\text { Tea, juice, homemade } \\
\text { syrup }\end{array}$ & $\begin{array}{l}\text { Influenza, intestinal, kidney and stomach } \\
\text { infections, insomnia, intestine, insect bite }\end{array}$ & Nurse, community health agents \\
\hline
\end{tabular}

In this study, it was verified that health professionals believe in the clinical effectiveness of medicinal plants and herbal medicines, however, less than half prescribes/indicates for their patients. This result may possibly be due to the lack of knowledge about scientific evidence in clinical practice, since the terms associated with it as a justification of the belief in its effectiveness were mostly "own knowledge," "effectiveness proven by a third part" and "family member's indication", terms that are not associated with evidence-based practice.

Although there are national policies that regulate the use of phytotherapy in national health programs in Brazil, there is no training of the health professionals for use of phytotherapy in clinical practice. Information on the clinical indication for its use are necessary to establish good practice that ensures the authenticity, safety and efficacy of traditional medicines and therapies. ${ }^{20}$

About the medicinal plants identified in the health units, it is verified that the vegetal part most used and prescribed/indicated by health professionals was the leaves. Ethnobotanical studies carried out in several regions of Brazil describe the leaves as the most used plant part in the preparations with medicinal plants. ${ }^{21-23}$

With regard to (About) homemade preparations, tea was the most prescribed and used form of preparation by health professionals. This result is in agreement with other researches that describe the infusion and decoction of the leaves as main means of preparation of the medicinal plants. ${ }^{24}$ In study conducted by Messias, et al. ${ }^{24}$, most of the interviewers prefer to prepare medicinal plants by infusion (tea) and decoction, and most of the medicinal plants are coming from the cultivation in own residence.

When comparing the most prescribed/indicated medicinal plants with the scientific literature, most of them already been studied pharmacologically. For example, Alasbahi \& Melzig ${ }^{25}$ describe the role of P. barbatus ("boldo") in the regulation of gastric secretion as well as its antinociceptive effect in abdominal pain. In another study, Costa, et al. ${ }^{26}$ report the anxiolytic activity of the C. citratus ("capim-santo").

Among the plants used via topical, "sambacaitá" (M. pectinatum) and "aroeira" (S. terebinthifolius) are indicated as adjuvants in the treatment of urogenital infections. As regards to "sambacaitá, the methanolic extract of the aerial parts of this species presented antimicrobial activity against Staphylococcus aureus, Bacillus subtilis and Streptococcus mutans, pathogenic bacteria that cause diseases in humans. ${ }^{27-29}$ With regard to "aroeira", highlights its anti-inflammatory, being widely used for the intimate hygiene of women users of the health units. Gilbert and Favoreto, ${ }^{30}$ describes the anti-inflammatory activity of the $S$. terebinthifolius leaves and bark. Therefore, this medicinal plant should be carefully used when for personal hygiene, because of its appendages that may cause irritation.

The species C. ambrosioides ("mastruz") is widely used for the treatment of worms, especially among children. MacDonald, et al. ${ }^{31}$ described the usage of the infusions of this species, utilized for centuries in the Americas, as a popular remedy against intestinal worm infections. These authors yet conclude that the usage of C. ambrosioides infusions as a vermifuge appear to be safer than the use of the herb's essential oil, rich in ascaridole.

The plant A. vera ("babosa") is commonly used by health professionals for the treatment of burns and in wound healing. Its application on the affect area is performed three times a day, as recommended by the national sanitary surveillance ${ }^{[32]}$. According to Maenthaisong, et al. ${ }^{33}$ there are evidences that demonstrate the effectiveness from the A. vera in the treatment of burns and healing process of wounds in patients with lesions of first and second degree.

Further, we can also conclude that some plants prescribed in the health units for the treatment of minor disturbances were not observed in the medicinal garden from the unit. These plants were the following: M. officinalis ("erva-cidreira"), M. sylvestris ("malva-branca"), M. chamomilla ("camomila"), S. barbatiman ("barbatimão") and A. sativum ("alho"). The species M. officinalis ("erva-cidreira") is mainly prescribed for the treatment of the anxiety and flatulence. Alijaniha, et $a .^{34}$ described the safety and effectiveness of $M$. officinalis in patients suffering from benign palpitations, and as a promising anxiolytic drug without any considerable side effects. Amsterdam, et al. ${ }^{35}$ reported a 
modest anxiolytic activity of $M$. chamomilla extract in patients with mild to moderate Generalized Anxiety Disorder.

According to the Ministry of Health, more than 30 million Brazilians suffer from high blood pressure predominance of higher plants used for arterial hypertension in Northeast region of Brazil in comparison with the other Brazilian regions. ${ }^{36,37}$ Further, the use of these medicinal plants in the basic care occurs especially among the elderly. ${ }^{38}$ In our study, we verified the concomitant use of garlic tincture (A. sativum) and other medications for the treatment of hypertension. In 2013, Ried, et al. ${ }^{39}$ suggested in their clinical trial aged garlic extract to be an effective and tolerable treatment in uncontrolled hypertension and may be considered as a safe adjunct treatment to conventional antihypertensive therapy.

Thereat, it would be interesting to cultivate these species in the horticulture of the health unit, allowing their safe use and consequently avoiding possible damages to the patients. Moreover, the cultivation of medicinal plants should be carried out using the utmost care, avoiding chemical contaminants such as heavy metals and pesticide residues, as well as other situations that may lead to intoxication among users of medicinal plants..$^{40,41}$

Regarding to knowledge about the current legislation involving medicinal plants and phytotherapics, the health staff reported knowing the NPMPP, however, a lack of knowledge about the existence of the NPGMPP was prevalent. Most plants found in the alive pharmacy are not included in the list of medicinal plants of interest for SUS (RENISUS). This fact probably occurs for several reasons: Brazil possesses continental dimensions and an enormous biodiversity coupled with a rich ethnic and cultural diversity that has valuable traditional knowledge associated with the use of plants. ${ }^{4}$

Precarious knowledge about the NPGMPP is one of the possible obstacles to the implantation of phytotherapy in primary health care, since this document is an indispensable tool for the managers and professionals involved in structuring the actions to strengthen this policy in the FHS, establishing criteria for the use of medicinal plants in the different levels of complexity of the SUS, as well as strategies to promote fundraising. ${ }^{5}$

With regard to the legislation on alive pharmacy, most interviewees were unaware of the ordinances and resolutions about the issue. ${ }^{42,43}$ Knowledge about legislation is essential, since provides good practices for processing and storage of medicinal plants in the SUS. In this study, the inadequate knowledge about alive pharmacy legislation may be an obstacle to the implantation of the medicinal garden in the three health units that do not have it.

Further, we verified that the only health unit that had a medicinal garden did not have a suitable place for the storage of medicinal plants. The preservation of the active principles can be compromised due to inadequate drying and storage. For example, degradation may occur through metabolic processes, hydrolysis, light, enzymatic action, oxidation, fermentation, heat and microbiological contamination. ${ }^{40}$

Most of the prescriptions of medicinal plants are based on popular use or monographs, although the Ministry of Health provides documents for the clinical practice of phytotherapy. The use of protocols can help to break the barriers regarding the use of medicinal plants in primary care, providing a description about the part of the used plant, its therapeutic indication and possible contraindications.

In addition to the above, the health unit with medicinal garden had no pharmacist and agronomist. The activities performed in the alive pharmacy are interdisciplinary, going through the physician, responsible for diagnosis and treatment orientation; pharmacist, responsible for the identification of plants and guidance from collection to preparation and quality control of herbal remedies; and the agronomist, responsible for the guidance of good practices of cultivation and preparation of seedlings. ${ }^{44}$ The lack of these professionals is possibly a risk factor for the safe use of medicinal plants in the health unit.

With regard to the health units that did not possess medicinal garden, all had available area for the cultivation of medicinal plants. The cultivation areas were exposed to the sun for at least five hours, had space protected against strong winds and good availability of water for irrigation, as recommended in the literature. The strong winds can cause damage to the plants, breaking their branches and stem, besides removing the fertile surface layer of the soils. In this context, medicinal tree species such as "aroeira" (S. terebinthifolius), "mulungu" (Erythrina velutina Willd.), "barbatimão" (Stryphnodendron adstringens) and fruit trees (banana trees) are important in the protection against strong winds. ${ }^{13,14}$

Despite the presence of these favorable traits for cultivation, two of the analyzed health units were exposed to pollution sources such as roads, septic tanks and streams, making cultivation unviable. When establishing the place of cultivation, it is necessary to recognize the environmental conditions (availability of luminosity, humidity, soil fertility) and avoid cultivation in areas in which there is circulation of domestic animals, such as dogs and cats, to avoid contamination. ${ }^{14,40}$

About the knowledge acquired during graduation, all the professionals stated that they had not had any discipline or course on the subject. This data is an obstacle to the insertion of phytotherapy, since the professionals do not have the necessary qualification to act with this therapeutic practice. According to Oliveira, et $a l .{ }^{45}$, phytotherapy evolves the knowledge about the curative power of plants and can no longer be considered popular or traditional, but a science that has been studied, perfected and applied over time. For the practice of herbal medicinal care, an academic formation that supports it is necessary, through the formal inclusion, contents and curricular experiences (in the undergraduate and postgraduate) to act in this specific field of knowledge. ${ }^{46}$

\section{CONCLUSION}

Despite the intention to use phytotherapy as therapeutic practice, it can be inferred that this integrative practice is not completely inserted in the analyzed health units, due to factors such as the lack of training and specific protocols to assist professionals about the use of medicinal plants and herbal medicines. In addition, for its effectiveness is necessary to implement the alive pharmacy in more than one health unit, serving certain territories as recommended in the SUS. In this context, it is interesting the articulation of the city government with other instances, training professionals not only for clinical practice, but also for management, given the incipient knowledge verified in this study.

\section{ACKNOWLEDGEMENT}

This study was financed in part by the Conselho Nacional de Desenvolvimento Científico e Tecnológico - Brasil (CNPq) and the Coordenação de Aperfeiçoamento de Pessoal de Nível Superior - Brasil (CAPES).

\section{CONFLICTS OF INTEREST}

There is no conflicts of interest.

\section{ABBREVIATIONS}

SUS: Unified Health System; WHO: World Health Organization; CHA: Community Health Agents; NPMPP: National Policy of Medicinal Plants and Phytotherapics; NPGMPP: National Program of Medicinal Plants and Phytotherapics; GHP: Graduated Health professionals; FHS: 
Family Health Strategy, RENISUS: List of medicinal plants of interest for SUS; PHC: Primary Health Care.

\section{REFERENCES}

1. World Health Organization (WHO). Traditional Medicine Strategy 2014-2023. Geneva: WHO; 2013

2. Petrovska BB. Historical review of medicinal plants' usage. Pharmacogn Rev. 2012;(6):1-5.

3. BRASIL. Ministério da Saúde (MS). Secretaria de Atenção à Saúde. Departamento de Atenção Básica. Política Nacional de Práticas Integrativas e Complementares no SUS. Brasília: MS; 2006a.

4. BRASIL. Ministério da Saúde (MS). Secretaria de Ciência, Tecnologia e Insumos Estratégicos. Departamento de Assistência Farmacêutica. Política Nacional de Plantas Medicinais e Fitoterápicos. Brasília: MS; 2006b.

5. BRASIL. Ministério da Saúde (MS). Secretaria de Ciência, Tecnologia e Insumos Estratégicos. Departamento de Assistência Farmacêutica e Insumos Estratégicos. Programa Nacional de Plantas Medicinais e Fitoterápicos. Brasília: MS; 2009

6. Figueiredo CA, Gurgel IGD, Junior GDG. A política nacional de plantas medicinais e fitoterápicos: Construção, perspectivas e desafios. Physis: Rev Saúde Col. 2014;24:381-400.

7. Victora CG, Barreto ML, Leal MC, Monteiro CA, Schmidt MI, Paim J, et al. Health conditions and health-policy innovations in Brazil: the way forward. Lancet. 2011;377:2042-53.

8. Macinko J, Harris MJ. Brazil's family health strategy - Delivering communitybased primary care in a universal health system. N Engl J Med. 2015;372:217781.

9. Center of Disease Control (CDC) (2012). EPI Info'T for DOS vis. Available from: https://www.cdc.gov/epiinfo/index.html. Division of Public Health Surveillance and Informatics.

10. Bardin, L. Análise de conteúdo. 3th ed. Lisboa: Edições 70;2004.

11. Portal da saúde. Plantas De Interesse Ao SUS, May 06, 2014. [Internet Website]. [Accessed on Dec 06, 2016]. Available from: http://portalsaude. saude.gov.br/index.php/o-ministerio/principal/leia-mais-o-ministerio/465-sctieraiz/daf-raiz/ceaf-sctie/fitoterapicos-cgafb/l1-fitoterapicos/12552-plantas-deinteresse-ao-sus.

12. CEARÁ. Decreto do Governo do Estado $n^{\circ} 30.016$, Dec 30, 2009. Aprovado Regulamento Técnico da Fitoterapia no Serviço Público do Estado do Ceará.

13. Azevedo CD, Moura MA. Cultivo De Plantas Medicinais Guia Prático, Niterói: Programa Rio Rural; 2010.

14. Carvalho LM. Embrapa. Orientações técnicas para o cultivo de plantas medicinais, aromáticas e condimentares. Aracaju: Embrapa, Circular Técnica, 70;2015.

15. BRASIL. Ministério da Saúde (MS). Secretaria de Atenção à Saúde. Departamento de Atenção Básica. Práticas integrativas e complementares: plantas medicinais e fitoterapia na Atenção Básica. Brasília: MS; 2012.

16. Marques LAM, Vale FVVRD, Nogueira VADS, Mialhe FL, Silva LC. Atenção farmacêutica e práticas integrativas e complementares no SUS: conhecimento e aceitação por parte da população São Joanense. Physis. 2011;21:663-74.

17. Marsiglia RMG. Perfil dos trabalhadores da atenção básica em saúde no município de São Paulo: região norte e central da cidade. Saúde e Soc. 2011;2):900-11.

18. Renata CS, Ana DS, Amuzza APS, Gilberto SC. Plantas medicinais utilizadas na saúde da mulher: riscos na gravidez. Diálogos \& Ciênc. 2012;32:241-6.

19. Posadzki P, Watson L, Ernst E. Herb-drug interactions: An overview of systematic reviews. Br J Clin Pharmacol. 2013;73:603-18.

20. World Health Organization (WHO). National policy on traditional medicine and regulation of herbal medicines: report of WHO global survey. Geneva: WHO; 2005.

21. Souza MD, Fernandes RR, Pasa MC. Estudo etnobotânico de plantas medicinais na comunidade São Gonçalo beira rio, Cuiabá, MT. Revista Bio. 2010;9:91-100.

22. Lima RA, Magalhães AS, Santos MRA. Ethnobotanical survey of medicinal plants used in the city of Vilhena, Rondônia. Revista Pesquisa e Criação. 2011;10:165-79.

23. Freitas AVL, Coelho MFB, Maia SSS, Azevedo RAB. Plantas medicinais: um estudo etnobotânico nos quintais do Sítio Cruz, São Miguel, Rio Grande do Norte, Brasil. R bras Bioci. 2012;10:48-59.
24. Messias MCTB. Uso popular de plantas medicinais e perfil socioeconômico dos usuários: um estudo em área urbana em Ouro Preto, MG, Brasil. Rev Bras Plantas med. 2015;17:76-104.

25. Alasbahi RH, Melzig MF. Plectranthus barbatus: a review of phytochemistry ethnobotanical uses and pharmacology-part 2. Planta medica. 2010;76:753-65

26. Costa CA, Kohn DO, de Lima VM, Gargano AC, Flório JC, Costa M. The GABAergic system contributes to the anxiolytic-like effect of essential oil from Cymbopogon citratus (lemongrass). J Ethnopharmacol. 2011;197:828-36.

27. Rojas A, Hernandez L, Pereda-Miranda R, Mata R. Screening for antimicrobial activity of crude drug extracts and pure natural products from Mexican medicinal plants. J Ethnopharmacol. 1992;35:275-83.

28. Fragoso-Serrano M, Gibbons S, Pereda-Miranda R. Anti-staphylococcal and cytotoxic compounds from Hyptis pectinate. Planta Med. 2005;71:278-80.

29. Nascimento PF, Alviano WS, Nascimento AL, Santos PO, Arrigoni-Blank MF de Jesus RA, et al. Hyptis pectinata essential oil: Chemical composition and anti-Streptococcus mutans activity. Oral Dis. 2008;17:485-9.

30. Gilbert B, Favoreto R, Schinus terebinthifolius. Raddi Rev Fitos. 2011;6:43-56.

31. MacDonald D, VanCrey K, Harrison P, Rangachari PK, Rosenfeld J, Warren C, Sorger G. Ascaridole-less infusions of Chenopodium ambrosioides contain a nematocide(s) that is(are) not toxic to mammalian smooth muscle. J Ethnopharmacol. 2004;92:215-21.

32. BRASIL. Agência Nacional de Vigilância Sanitária (Anvisa). Memento fitoterápico: farmacopeia brasileira. Brasília: Anvisa; 2016.

33. Maenthaisong R, Chaiyakunapruk N, Niruntraporn S, Kongkaew C. The efficacy of aloe vera used for burn wound healing: A systematic review. Burns. 2007;33:713-8

34. Alijaniha F, Naseri M, Afsharypuor S, Fallahi F, Noorbala A, Mosaddegh M, et al. Heart palpitation relief with Melissa officinalis leaf extract: double blind randomized, placebo-controlled trial of efficacy and safety. J Ethnopharmacol. 2005;22:378-84

35. Amsterdam JD, Li Y, Soeller I, Rockwell K, Mao JJ, Shults J. A randomized double-blind, placebo-controlled Trial of oral Matricaria recutita (chamomile) extract therapy of generalized anxiety disorder. J Clin Psychopharmacol. 2009;29:378-82

36. Portal Brasil. Hipertensão atinge mais de 30 milhões de pessoas no País, Apr 22, 2015. [Internet Website]. [Accessed on Dec 09, 2016]. Available from: http:// www.brasil.gov.br/saude/2015/04/hipertensao-atinge-mais-de-30-milhoes-depessoas-no-pais.

37. Fátima AM, Nurit SK, Diniz BIJL, França FP, Maria BFJ. Survey of medicinal plants used in the region Northeast of Brazil. Rev. bras. farmacogn. 2008;18:472-508.

38. Brasileiro BG, Pizziolo VR, Matos DS, Germano AM, Jamal CM. Plantas medicinais utilizadas pela população atendida no "Programa de Saúde da Família", Governador Valadares, MG, Brasil. Braz J Pharm Sci. 2008;44:629-36.

39. Ried K, Frank OR, Stocks NP, Fakler P, Sullivan T. Effect of garlic on blood pressure: A systematic review and meta-analysis. BMC Cardiovasc Disord 2008;8.

40. Bochner R, Fiszon JT, Assis MA, Avelar KES. Problemas associados ao uso de plantas medicinais comercializadas no Mercadão de Madureira, município do Rio de Janeiro, Brasil. Rev bras plantas med. 2012;14:537-47.

41. Veiga-Junior VF. Estudo do consumo de plantas medicinais na Região CentroNorte do Estado do Rio de Janeiro: aceitação pelos profissionais de saúde e modo de uso pela população. Rev Bras Farmacogn. 2008;18:308-13.

42. BRASIL. Ministério da Saúde. Agência Nacional de Vigilância Sanitária Resolução da Diretoria Colegiada n. 18, Abr 03, 2013. Dispõe sobre as boas práticas de processamento e armazenamento de plantas medicinais, preparação e dispensação de produtos magistrais e oficinais de plantas medicinais e fitoterápicos em farmácias vivas no âmbito do Sistema Único de Saúde (SUS). Diário Oficial da União da República Federativa do Brasil, Brasília, Apr 05, 2013.

43. BRASIL. Ministério da saúde. Portaria MS 886, Apr 20, 2010. Institui a Farmácia Viva no âmbito do Sistema Único de Saúde (SUS).

44. Matos FJA. Farmácias vivas: sistema de utilização de plantas medicinais projetado para pequenas comunidades. 8th ed. Fortaleza: Editora UFC; 2002

45. Oliveira CJ, Araújo TL. Plantas medicinais: usos e crenças de idosos portadores de hipertensão arterial. Revista Eletrônica de Enfermagem. 2007;9:93-105

46. Alvim NAT, Ferreira MA, Cabral IE, Almeida Filho AJ. O uso de plantas medicinais como recurso terapêutico: das influências da formação profissional às implicações éticas e legais de sua aplicabilidade como extensão da prática de cuidar realizada pela enfermeira. Rev Latino-Am Enfermagem. 2006;14:31623.

Cite this article: Souza CAS, Andrade WMG, Ramos TS, Filho AJS, Freitas AL, Lima TC, et al. Medicinal Plants in Basic Care: A Study of Clinical Practice. Pharmacog J. 2019;11(4):796-802. 